\title{
Standardisering $\mathrm{i}$ arbejdet
}

\section{- mellem magtfuldt og magtesløst}

\author{
En empirisk analyse af Post Danmarks \\ ruteplanlægningssystem og dets konkrete effekter
}

\section{Mette Mogensen}

Standardisering af arbejdet forbindes generelt med ufrihed, ensformighed og fremmedgørelse af arbejderen. En kritik som først og fremmest har været baseret på og rettet mod Taylorismen. Med et empirisk afsæt i Post Danmarks ruteplanlægningssystem (TOR) argumenterer artiklen imidlertid for at standardisering må forstås og evalueres langt mere empirisk/pragmatisk. Inspireret af Aktør-Netværks-Teori analyseres ruteplanlægningssystemets standardiserende effekt som co-determineret af mange aktører, der tilsammen giver standardiseringsbestræbelsen sin gennemslagskraft. Pointen er at standardisering ikke nødvendigvis virker som følge af en optimal rationalisering, baseret på en skarp opdeling i planlægning og udførelse, sådan som taylorismen foreskriver. I Post Danmark er det reelt først i samspillet med langt 'blødere' og postbureaukratiske styreformer at standardiseringen af postarbejdet får effekt og bliver magtfuldt.

\section{Taylor og spørgsmålet om 'a fair day's work'}

$\mathbf{W}_{\text {let om standardisering af arbejdet, er }}^{\text {å man skal forholde sig til spørgsmå- }}$ Frederick. W. Taylor og 'scientific management' uomgængelig. Taylors grundlæggende ambition var at finde den bedste, dvs. den mest effektive, måde at udføre en given arbejdsfunktion på, uanset om det handlede om at skovle eller at transportere jern. Ambitionen blev indfriet ved at erstatte det Taylor betegnede som arbejdernes 'rule of thumb' med videnskabeligt baserede opmålinger af arbejdet. Helt konkret ved at lade ingeniører observere og tidsudmåle hver enkelt arbejdsopgave for på den måde at kunne identificere 'the elementary operations or motions' (Taylor 2004, 41) og dernæst pege på den mest optimale måde at udføre dem på. Taylor understregede samtidigt at arbejdsmængden skulle være nøje afstemt, ikke blot mellem arbejdsopgave og tid, men ligeledes i forhold til den enkelte arbejders formåen. Som Taylor understregede så var ambitionen ikke at lade den enkelte knokle så meget som muligt, men at finde nøjagtigt det punkt hvor hensynet til produktiviteten og arbejderens velbefindende kunne balancere. Netop dét punkt gav Taylor betegnelsen 'a fair day's work':

"Now it must be clearly understood that in these experiments we were not trying to find the maximum work that a man could do on a short spurt or for a few days, but that our endeavor was to 
learn what really constituted a full day's work for a first-class man; the best day's work that a man could properly do, year in and year out, and still thrive under" (Ibid, 19).

Når det handlede om at skovle blev det således et spørgsmål om at identificere, om det var 20, 25 eller måske 40 pund skovlen skulle fyldes med for hvert tag, for at en arbejder ville kunne gentage operationen det antal gange som produktionen tilsagde uden at blive slidt ned.

Baggrunden for Taylors ambitioner var ikke mindst at der på det pågældende tidspunkt var et pres på den amerikanske stålindustri i forhold til at øge produktiviteten, samtidig med at de meget store fabrikker var vanskelige at styre og generelt repræsenterede et højt konfliktniveau mellem parterne (Kjær 2014). Taylor delte for så vidt den generelle mistillid til medarbejderne, som han opfattede som grundlæggende dovne af natur og derfor generelt optaget af at yde mindre end de reelt var i stand til. De faste standarder for en fair arbejdsdag ville på den måde gøre en ende på arbejdernes systematiske 'soldiering' (Taylor 2004, 7). Taylor havde dog samtidigt en idé om at standardiseringen, jf. dens balancegang mellem produktivitet og medarbejdertrivsel, ville kunne fungere som svaret på de mange konflikter i industrien på daværende tidspunkt. De videnskabeligt definerede kriterier for arbejdet blev set som et neutralt standpunkt, der kunne yde begge parter retfærdighed. Standardisering af arbejdet ville én gang for alle afskaffe arbejdskonflikter, argumenterede Taylor (Ibid, 49).

\section{Humanisternes kritik}

Ser man på Taylors 'scientific management', er en af de helt store forskelle fra tidligere tiders måde at organisere arbejdet at med- arbejderne fratages indflydelse på deres arbejde. Faglighed, erfaring og individuelle skøn, såkaldt 'rules of thumb', blev af Taylor fjernet til fordel for videnskabelige standarder for et godt stykke arbejde. Det er som en direkte modreaktion herpå at 'Human Relations'-skolen blot få årtier senere fremhæver de menneskelige og sociale dimensioners betydning for produktiviteten. Baseret på Hawthorne-studiernes forsøg med belysning og andre fysiske arbejdsvilkår må forskerne notere sig at den mest afgørende faktor for den observerede produktivitetsstigning lader til at være forårsaget af den positive opmærksomhed, som eksperimentet selv forlener arbejderne med. Et resultat som dannede skole for en langt mere humanistisk tilgang til produktionen, hvor arbejdernes psyke og socialitet blev en naturlig del af ledelsesopgaven (Roethlisberger \& Dickson 1964; Grey 2009; Rose 1990). Det er ligeledes i opposition til Taylor at Braverman formulerer sin 'de-skilling'-tese. En kritik, der netop var rettet mod et produktionsprincip, som gør alt for at sætte medarbejderens faglige evner og skøn ud af kraft (Braverman 1974). Og endelig er det her Robert Karasek, som på mange måder står fadder til forskningen i det psykiske arbejdsmiljø, tager sit afsæt idet han indsætter medarbejderens grad af kontrol i arbejdet - som buffer mod stigende krav i arbejdet og således som væsentlig forudsætning for medarbejdernes fortsatte trivsel (Karasek 1979). Mens Taylor og ligesindede argumenterer for at standardisering fører til en højere grad af retfærdighed i opgavemængden, en bedre belønningsstruktur og samtidigt større arbejdertilfredshed, kritiserer humanisterne ham for det præcist modsatte. Som kritikerne fremfører, udspringer standardisering typisk af ledelsens interesse i større produktivitet, mens medarbejderne i samme åndedrag efterlades som den part der mister kontrol i 
et arbejde der før var defineret ved individuelle vurderinger og faglige normer. Det tayloristiske produktionsapparat efterlader følgeligt medarbejderen fremmedgjort, reduceret til en de-humaniseret og passiv forlængelse af produktionsapparatet:' a cog in the wheel' (se også: March \& Simon 1958; Morgan 1989).

Den form for kritik er langt fra forstummet. Som Paul Du Gay argumenterer for, er opgøret med standarder, regler og procedurer nærmest blevet en 'default-position' i forskningslitteraturen såvel som i den offentlige debat ${ }^{1}$. At være fortaler for såkaldte post-bureaukratiske organiseringsformer bliver pr. definition anset som den legitime position, dér hvor man allierer sig med det nye, det fremtidsorienterede og ikke mindst det menneskelige. Heroverfor står bureaukratiske styreformer (herunder Taylorismen) som det gammeldags og grundlæggende inhumane (Du Gay 2000).

I tråd hermed vil jeg argumentere for at kritikken af standardisering ofte har et idealistisk præg. Den forudsætter ikke mindst at Taylors 'scientific management' rent faktisk fungerer efter forskrifterne. At det reelt lader sig gøre at organisere arbejdet jævnfør en beslutningsrationel forståelsesramme, med ledelsen i den toneangivende position. Det er ikke tilfældigt at det ofte er ledelse og relationen mellem ledere og medarbejdere der stjæler fokus, når standardisering i arbejdet diskuteres. Netop differentieringen af roller mellem ledere og medarbejdere som hhv. planlæggende og udførende var det helt centrale bidrag i Taylors principper for 'scientific management'. Det var i det hele taget med Taylor at ledelse tog form som en professionaliseret praksis (Taylor 1903; Mogensen 2000). Hvis man ser på standardisering som noget der gøres og omgøres i en specifik arbejdsorganisatorisk sammenhæng, tegner der sig imidlertid et andet og langt mere nuanceret billede hvor såvel Taylorismens som dens kritikeres idealiserede og beslutningsrationelle forklaringsramme må nuanceres ${ }^{2}$.

\section{Fra standardisering til hybride styreformer}

Denne nuancering er jeg samtidig ikke ene om. Når det handler om at forstå og konceptualisere nutidens styrings- og koordineringsformer, er billedet generelt blevet langt mere komplekst.

Der er således eksempler på hvordan man inden for de senere år også er begyndt at interessere sig for standardiseringens og bureaukratiets positive sider. Både i en dansk og international sammenhæng er det blevet fremført at standarder, regler og procedurer kan fungere som ressourcer for medarbejderne selv, når de skal orientere sig i et ellers komplekst og grænseløst arbejde (Kärreman et al. 2002; Buch et al. 2009; Du Gay 2000).

Omvendt har andre forskere inden for 'Critical Management Studies', hvilket også tæller danske forskere, helt forladt standardiseringsdiskussionerne til fordel for analyser og kritik af de såkaldte 'bløde' styreformer (repræsenteret ved f.eks. selvudviklingskurser, MU-Samtaler, selvstyrende teams etc.). De bløde styreformer fremhæves som karakteristiske for det moderne arbejdsliv og udmærker sig ved at omfavne og omforme humanisternes kritiske position til effektive men subtile selv-ledelsesformer (se f.eks. Tynell 2002; Bovbjerg 2003; Gudiksen 2007; Kunda 1992; Alvesson \& Willmott 2002). Disse analyser er både interessante og betimelige, men de har haft en tendens til at overdrive betydningen af selvledelsesproblematikkerne. Faktum er at Taylorisering af arbejdet langt fra er et overstået historisk kapitel, men at det tværtimod optræder i stadigt flere typer af brancher (Allvin et al. 2011; Alvesson \& Thompson 2005) og 
ikke mindst i nye hidtil usete kombinationer med netop post-bureaukratiske, 'bløde' tiltag. Disse såkaldte 'hybride' organiseringsformer er der netop flere forskere der er begyndt at fokusere på i et forsøg på at forstå konsekvenserne af sameksistensen af standardisering og forskellige former for selvledelse i arbejdet (Alvesson \& Kärreman 2004; Kärreman \& Alvesson 2004; Hvid et al. 2010; Kärreman et al. 2006). Svagheden ved disse analyser er imidlertid at de har en tendens til at fastholde et billede af standardisering og selvledelse som væsensforskellige styringsrationaliteter, der udspiller sig i et prædefineret spændingsfelt mellem leder og medarbejderinteresser (Mogensen

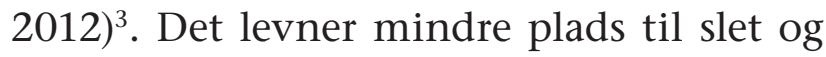
ret at beskrive hvordan forskellige styringspraksisser interagerer og smelter sammen. Ikke mindst vanskeliggør det en åbenhed overfor at spørgsmål om interesser kan være mere komplekst end en leder-medarbejder dikotomi tillader. Det er set i det lys at artiklen her bestræber sig på at vise hvordan standardisering af postarbejdet reelt kun fungerer ved at hente ressourcer fra medarbejderes, lokale lederes og artefakters aktive medspil. Konsekvenser af standardisering samt grænserne mellem standardisering og selvledelse - bureaukrati og post-bureaukrati - bliver et langt mere uafgjort spil. Konsekvenser såvel som grænser kan ikke drages a priori, men kun specifikt empirisk.

\section{Standardisering som distribueret 'agency'}

Den teoretiske inspiration til at analysere standardisering, som noget der gøres i praksis, henter jeg fra Aktør-Netværks-Teori, sådan som den er blevet udviklet af Bruno Latour, Michel Callon og John Law (Callon \& Latour 1981; Latour \& Woolgar 1986; Callon 1986; Latour 2005). I relation til at analysere og forstå standardisering i arbejdet vil jeg særligt hæfte mig ved tre elementer: spørgsmålet om agens/'agency', symmetri-princippet samt ANT's deskriptive ambition.

Når det handler om agens, er ANT's væsentligste pointe at handlekraft ikke kan forstås som noget der hidrører det enkelte individ, eller en specifik makrostruktur. Som Latour påpeger: "An actor is what is made to act by many others" (Latour 2005,46). Agens bliver på den måde redefineret fra at være en årsag, der forklarer, til at være en effekt, der skal forklares. Når jeg ønsker at undersøge standarder og standardisering i arbejdet, bliver det på den måde min opgave at beskrive ikke bare hvad standarderne gør, men samtidigt at se på hvorfra standarderne får deres handlekraft. Standarders eventuelle magtfulde karakter er således ikke noget som kan tilskrives dem selv eller en bagvedliggende intentionalitet, men må derimod forstås og analyseres som et resultat af det specifikke organisatoriske setup de er en del af.

Et meget illustrativt eksempel giver Latour i Pandora's Hope (Latour 1999) hvor han tager udgangspunkt i diskussioner om USA's våbenlovgivning. Mens nogen påpeger at våben er farlige, hævder andre at det er det menneske der håndterer det som er problemet. Heroverfor indsætter Latour en tredje mulig position, nemlig at et våbens farlighed nødvendigvis må forstås som den samlede effekt af våben + mand. Som Latour udtrykker det: "You are a different person with a gun in your hand" (Ibid, 179). Og vice versa: våbnet er ikke farligt i sig selv, men co-determineres af manden der bruger det. Spørgsmålet om farlighed kan med andre ord ikke tilskrives mand eller pistol hver for sig, men er og bliver en distribueret effekt. Eksemplet tydeliggør samtidig en anden væsentlig pointe i det ANTske univers, nemlig betydningen af non-humane aktører. Tekster, procedurer og maskiner som ellers normalt anses som 'døde' artefakter, betragtes alle som potentielt handlekraftige og analyseres på lige fod 
med de menneskelige med/modspillere. I bestræbelserne på at forfølge dette princip om symmetri mellem mennesker og ikke-mennesker henter jeg særlig inspiration i Madeleine Akrich's begreb 'Geographies of delegation' (Akrich 1992). Pointen hos Akrich er at forstå relationen mellem mennesker og teknologi (ikke-mennesker) som dynamisk og uafgjort. Som hun påpeger, vil spørgsmål om identitet, kompetencer og magt være noget som afgøres i den løbende forhandling - delegering - mellem mennesker og teknologi. En teknologis identitet bliver således defineret i den måde den bruges og relateres til andre objekter og mennesker på (Ibid, 206). Når man vil analysere standardisering i arbejdet ud fra denne optik, kalder det ikke mindst på en empirisk sensitivitet, hvilket er det tredje, men ikke mindre væsentlige analytiske princip som jeg vil fremhæve. I forsøget på at imødegå det jeg opfatter som standardiseringsdiskussionernes ofte idealiserede forståelsesramme, bliver en detaljeret beskrivelse af hvordan standardisering af arbejdet rent faktisk foregår, en væsentlig strategi. I denne artikelsammenhæng giver det naturligvis nogle begrænsninger i forhold til hvor stort et netværk det kan lade sig gøre at beskrive for læseren. I analysen af ruteplanlægningssystemet forsøger jeg ikke desto mindre at beskrive både de idéer og praksisser som til en start har defineret ruteplanlægningssystemets 'raison d'être': De konkrete forhandlinger af systemet, som foregår i en ruteomlægningsproces, samt de daglige diskussioner om arbejdstid, -mængder og ansvar, som kontinuerligt skaber tvivl om det systemet er designet til at levere det endegyldige svar på, nemlig: hvad er 'a fair day's work'?

\section{Artiklens kontekst og belæg}

Artiklen er baseret på min ph.d.-afhandling: "The Organizations of Well-being and Produ- ctivity - (Re) assembling work in the Danish Post", som var en del af forskningsprojektet TRIPS (Trivsel, Produktivitet og Selvledelse) og delvist finansieret af Arbejdsmiljøforskningsfonden ${ }^{4}$. Ph.d.-afhandlingens ambition er at studere sameksistensen af bureaukratiske og post-bureaukratiske ledelsesformer baseret på kvalitative og etnografisk inspirerede metoder. Det indbefatter auto-fotografi, enkelt- og gruppeinterviews, (deltagende) observation samt dokumentanalyse. Det empiriske fokus er organiseringen af postdistribution i Post Danmark. Geografisk/organisatorisk har det betydet at empirien er indsamlet både på det centrale niveau i HR og Distributionsudvikling i Post Danmarks Hovedkvarter, i HR og Distributionsudvikling på regionalt (postområde) niveau samt i to lokale distributionscentre nord for København. I denne analyse refererer jeg primært til fem kvalitative interviews med forskellige ledende kræfter i organisationen (på forskellige niveauer) samt til observationer i hhv. Postcenter København og i budstuen i Nordby ${ }^{5}$. Analysen er baseret på ph.d-afhandlingens kapitel fem og ni (Mogensen 2012), men er reelt et resultat af den viden om organisationen som kommer af ph.d.-afhandlingens samlede kilder og analytiske arbejde.

I analysen nedenfor beskriver jeg først den situation Post Danmark står i som virksomhed og dermed hvad det er standardiseringsbestræbelserne - repræsenteret ved et ruteplanlægningssystem (TOR) - er et svar på, set fra ledelsens side. Derefter beskriver jeg TOR's funktionalitet som system og hvordan 'a fair day's work' herigennem bliver fastlagt, eller rettere forhandlet. Analysen viser nemlig videre hvordan den optimale ruteplanlægning er langt fra perfekt, men tværtimod kræver et omfattende arbejde, repræsenteret ved både planlæggere, lokale ledere, medarbejderteams og artefakter for at forblive stabilt og funktionelt. 
Analysen peger til slut på at den arbejdstid og -indsats systemet skulle standardisere dukker op på ny - som interne forhandlinger i teamet mellem postarbejderne og mellem postarbejder og den lokale leder. Konklusionen bliver at standardiseringen kun fungerer fordi den samtidigt genindsætter medarbejdere og lokale ledere som ansvarligt yderste led i et produktionsapparat, der ellers ville bryde sammen.

Analysen er hele vejen igennem beskrivende $\mathrm{i}$ sin form, men det betyder ikke at den er neutral eller tilfældig. Den sigter mod at producere en (ny) fortælling om Post Danmark og en ny fortælling om standardisering, som forhåbentlig kan være med til at forskyde den gængse forståelse af hvad standardisering er og har af konsekvenser.

\section{Fra Morten Korch til automatiseret produktion}

"Jeg plejer at sige: I Morten Korch-filmene, der går postbuddet rundt i skjorteoermer. $O g$ han har en taske her, og det er det eneste han har af post. Og sådan er vores verden slet ikke. Postarbejde det er benhårdt arbejde. Der skal måske sloebes halvandet ton post ud $i$ dag. Der skal omdeles på ruten og i nogle brevkasser, der står ude ved vejen. Det er bare sådan, altså bare...det er et hårdt arbejde" (Regional driftudvikler)

Billedet af den røde uniform i landskabet kan indgyde indtrykket af at det at være postbud er en dans på roser. Et frit arbejde i pagt med naturens skiften. På engelsk går postbuddet under den hyggelige betegnelse 'community helper', og i populærlitteraturen er der mange eksempler på postbudsromantik; tænk bare på 'Vinterbyøster' eller alle børns 'Postmand Per'. Som driftudvikleren påpeger i citatet ovenfor, og som det også fremgår med al ønskelig tydelighed når man har opholdt sig i Post Danmark i ganske kort tid, så er postbuddet a la Morten Korch en saga blot. Postdistribution er hårdt arbejde, og ikke mindst er det i høj grad præget af standardisering og automatisering. I en tid mange ellers betegner som post-industriel, er Post Danmark på mange måder kendetegnet ved at være en traditionel industrivirksomhed. Igennem mange år, og i virkeligheden gennem hele sin nyere historie, har Post Danmark således været drevet af teknologiske forbedringer samt en stadig øget automatisering og effektivisering af distributionen. Når det handler om indførelse af ny teknologi, hører det danske postvæsen blandt de førende i verden. I første omgang har man fokuseret på for-sorteringen, som man i stigende grad har centraliseret og automatiseret. I dag er der således kun to store centre i Danmark, et i Århus og et i København, som sorterer og håndterer al den post som kommer ind i systemet - enten nationalt eller internationalt. Hvis du putter et brev i postkassen i Kalundborg med adresse samme sted, skal det således omkring et avanceret brevsorteringsmaskineri i København før det bliver returneret til et distributionscenter i Kalundborg og først hér falder i hænderne på de lokale postbude, der kan lade brevet ende sin rejse i den rette postkasse. Selvom den lange rejse umiddelbart virker irrationel, så taler den tyve meter lange sorteringsmaskine sit tydelige sprog: 40.000 breve bliver her sorteret på en time. Blot et par medarbejdere kredser opmærksomt omkring maskinen mens den arbejder på højtryk. De lange rækker af travle kvindehænder som førhen sorterede posten manuelt, er nu blot at finde på de sort-hvide fotografier der hænger rundt omkring på centrets gange.

For nylig er man også begyndt at fokusere på den del af distributionen som endnu er kendetegnet ved at være medarbejdertung: nemlig omdelingen. I løbet af 00'erne har man således udviklet et meget avanceret og 
ambitiøst it-system der i dag fungerer som det primære værktøj til styring og koordination af postomdelingen i Danmark. Systemet kaldes 'TOR', hvilket står for Transport Og Ruteplanlægningssystem. Formålet med TOR er at standardisere omdelingen af post således at geografi (ruter), tidsforbrug og arbejdskraftressourcer koordineres så optimalt som muligt i forhold til hinanden. Set i et økonomisk perspektiv sparer TOR Post Danmark for mange millioner af kroner, alene som følge af sparede kilometer og mandetimer. I 2011 estimerede man således at TOR havde sparet organisationen for omkring 34 mio. kroner. For kun få år tilbage var ruteomlægninger noget der foregik ca. en gang årligt. Aktuelt er det en proces som foregår mere eller mindre hele tiden. Ikke i form af fulde omlægninger af samtlige ruter (hvilket typisk foregår hver tredje til sjette måned), men som løbende tilpasninger af enkelte ruter i takt med nedgangen af post. Af samme grund betragtes TOR af den øverste ledelse som et væsentligt og samtidigt fleksibelt redskab til at håndtere en ellers meget vanskelig situation med faldende postmængder og et fuldt liberaliseret postmarked.

TOR ses samtidigt som en kærkommen lejlighed til at få et fastere greb om medarbejderne og deres tid. Særligt den såkaldte 'udetid', som er den der tilbringes på ruten. Som en HR-chef udtrykker det:

"Vi er $i$ den situation når medarbejderne er ude af døren, så har vi mistet kontrollen. Det har vi jo. Den tid der går til medarbejderen er tilbage igen, er fuldstoendigt styret af medarbejderen. Og hvis medarbejderen, lidt firkantet sagt, siger: 'Jeg kan ikke nå det $i$ dag', og lederen siger: 'det tror jeg godt du kan', så kan medarbejderen altid bevise at vedkommende har ret. Det må man da sige, er selvledelse så det batter. Vi styrer ikke arbejdstiden". (Regional HR-chef)
TOR kan altså ses som et muligt svar på den bekymring HR-chefen her sætter ord på, nemlig at de lokale ledere reelt har meget vanskeligt ved at kontrollere postbudenes arbejdsindsats og tid så snart de forlader distributionscentrene og begiver sig ud på deres ruter.

\section{Den optimale rute}

Udover at kombinere input fra GIS, adressedatabaser, estimerede budgetter for det kommende års besøgsfrekvenser samt kvalitetsmål for udbringning (som er fastlagt ved lov) består en væsentlig del af TOR af en meget detaljeret definition og tidsudmåling af samtlige delprocesser i omdelingen. Der er således lavet en minutiøs opregning af nøjagtigt hvilke arbejdsprocesser der indgår i det at uddele post, og ikke mindst hvor lang tid hver enkelt delproces tager, udregnet ned til brøkdele af sekunder. Tidsopmålingen omfatter såvel humane som non-humane aktører:

Hvad angår de non-humane aktører, drejer det sig eksempelvis om knallerter, cykler og biler, eftersom valg af transportmiddel selvsagt har en stor betydning for tidsudmålingen og dermed også tilrettelæggelsen af den enkelte rute. I bymæssig bebyggelse og evt. kombineret med høje besøgsfrekvenser kan det således bedst betale sig at bruge cykel, mens landruter med langt mellem husene kalder på bilen som det mest effektive transportmiddel. Desuden indregnes vejens specifikke karakteristika, dvs. om der er tale om en landevej, en stille villavej eller en smal grussti på landet. På den måde spiller også vejens 'fysik' og gældende færdselsregler en rolle i TOR's beregninger. Når det gælder de humane aktører, postbudene, så definerer systemet nøjagtigt hvor meget tid de forventes at bruge på hver enkelt bevægelse på ruten: Hvor mange sekunder det tager at gribe ned i tasken og få fat i po- 
sten, hvor lang tid det tager at putte det i postkassen på bestemmelsesstedet, hvor lang tid det tager at tilbagelægge strækningen mellem adresser og hvor lang tid det tager at kontakte kunder i forbindelse med pakkeudbringning. Sidstnævnte beregning beror desuden på anden data, der kan differentiere imellem hvorvidt en given adresse er tilmeldt den flexordning som gør det muligt for postbuddet at efterlade pakken i carporten, og på den måde spare de sekunder det tager at banke på og vente på svar.

Alle disse data kalibrerer TOR for i sidste ende at kunne oversætte dem til en specifik geografi og rutelogistik, der samtidigt nøjagtigt svarer til hvad man kan forvente af en fuld arbejdsdag på 7,24 timer. Kombineret med den automatiserede for-sortering af breve, som knytter det enkelte brev til en specifik geografisk placering (via postnummeret) og dermed en rute, er TOR således med til at skabe en komplet mål- og styrbar brevproduktion i Post Danmark. Brevets rejse gennem produktionsapparatet, såvel som omdelernes arbejde, er takket være TOR defineret og kalkuleret ned til mindste detalje.

Set i relation til Taylors oprindelige ambitioner lader TOR meget lidt tilbage at ønske. Det drejer sig ikke om at skovle kul, men principperne er tydeligvis de samme. Baseret på avanceret data, tidsstudier og med involveringen af eksperter som ingeniører og it-specialister er TOR på mange måde et kongseksempel på 'scientific management'. Før TOR kom til, udlagde man typisk nye ruter ved at lade erfarne postbude sætte sig sammen og komme med en første skitse til en ny ruteføring. Men som driftudvikleren udtrykker det, var problemet at de var alt for konservative og forankret i gamle vaner. De var for knyttet til deres gamle ruter til for alvor at kunne se på tingene på ny. Heroverfor står TOR uden historik, præferencer og erfaringer i forhold til gamle rutestrukturer og er derfor i stand til med et nøgternt blik 'at smide alt op i luften', som driftudvikleren udtrykker det. Igen er parallellen til Taylor tydelig i og med at det netop var medarbejdernes såkaldte 'rules of thumb' som den nye form for arbejdsorganisering var rettet imod. Tommelfingerreglerne var baseret i den enkeltes faglighed og erfaringer, men kunne ifølge Taylor ikke stå mål med en arbejdsorganisering baseret på en videnskabeligt baseret udmåling af tid og arbejdsindsats.

Set i et styringsmæssigt perspektiv udgør TOR således den ultimative form for standardisering af arbejdet og fungerer som svar på de bekymringer man ledelsesmæssigt har haft - og fortsat har - med at få styr på udetiden samt det man fra ledelsesmæssig side har opfattet som postbudenes egenrådige adfærd. Desuden, og også helt i tråd med Taylor, fremhæves TOR som et langt mere retfærdigt system end tidligere ruteudlægningspraksis. Frem for ruter baseret på studehandler og interne styrkeforhold mellem postbude tilbyder TOR et neutralt blik og dermed en langt mere fair løsning. Et bud på 'a fair day's work'. Alle ruter har nøjagtigt den samme arbejdsbelastning, nemlig på 7,24 timer, og postbudene vil således, uanset hvilken rute de tildeles, skulle yde præcist den samme arbejdsindsats. Fodret med de rette informationer er TOR i modsætningen til postarbejderne i stand til at udlægge ruten på den mest optimale måde for hele organisationen. Argumentet er logisk-rationelt, men som det vil fremgå af de mange empiriske eksempler nedenfor, formår TOR langt fra at skabe den form for entydighed og styring i praksis som dens rationalitet tilsiger. Den oprindelige ide med TOR var at den skulle kunne producere grydeklare ruter. TOR's rutekort, der fremstår som fine røde linjer som zig-zagger frem og tilbage på landkortet, ser måske nok perfekte ud på papir, men viser at producere en lang række udfordringer i praksis. 


\section{At optimere det optimale}

En svaghed ved TOR's kalkulationer er eksempelvis dens evne til at repræsentere ruternes geografi, så det modsvarer den realitet postbudene møder på deres ruter. For det første er TOR's geografi flad. Det vil sige at TOR, via det geografiske informationssystem, ikke er i stand til at repræsentere en ganske væsentlig dimension i postomdelingen, nemlig forskellen på bakketop og bakkedal. Som driftudvikleren forklarer:

"For TOR er jo bare principielt en regnemaskine, som kan lave en frygtelig masse beregninger på én gang, og dermed finde den billigste måde at fragte eller at køre fra a til $b$. Der er jo ikke noget. Den tager ikke højde for bakker, eller ned ad bakke eller op ad bakke eller... Geografien er flad i TOR. Der er nogle veje der er tegnet ind på et kort, og det er dér TOR bevaeger sig. Og så er det klart, TOR kan jo ikke tage højde for at det går meget op ad bakke på den her, så der skal man sørge for at ruten ligger, så man kører ned ad med fuld taske og op ad med tom taske" (Regional driftudvikler)

Det betyder selvsagt meget for en rutes fremkommelighed - og dermed dens tidsudregning - hvorvidt bakker tilbagelægges nedefra og op eller omvendt. Med den gradvise indfasning af el-cykler i Post Danmark og den aflastning de tilbyder postbudene, vil netop det aspekt blive mindre betydningsfuldt, men indtil da vil den manglende tredje dimension fortsat være et væsentligt blindt punkt hos TOR. For det andet er TOR's geografi statisk. Spærrede stier, vejarbejde eller mængden af trafik på en vej kan give meget varierende udfald når det handler om at udregne den mest optimale rute. Hvis en rute eksempelvis lægges så en meget travl vej skal krydses flere gange, vil det både give forsinkelser, men også udsætte postbuddet for større risici i trafikken. For det tredje skelner TOR ikke mellem kvarterer. Som en af de to regionale planlæggere anfører, så mangler ruterne ofte logik, hvilket betyder at postarbejderne som regel ikke vil acceptere dem:

"Altså, når jeg kommer med et forslag, hvis der er for meget blanden sammen og for meget roderi, så vil de sige nej. Så vil de sige: 'Nej det holder ikke'. Men hvis det hoenger nogenlunde sammen, og logikken på ruten er fornuftig, så vil de sige: 'Jamen det er i hvert fald voerd at arbejde videre med'". (Regional planlægger)

Selvom en af fordelene ved TOR's standardiserede ruter er at det i princippet gør arbejdet langt mindre afhængig af personlige erfaringer i og med lokalområdet, så er det ifølge postbudene selv nemmere at køre en rute som er logisk opbygget, frem for én som blot er tidseffektiv. Pludselig at skulle springe over nogle veje, der ellers ligger i naturlig forlængelse af den enkeltes rute, giver ganske enkelt ikke mening og kan derfor øge sandsynligheden for fejl.

\section{A fair day's work?}

En anden væsentlig og paradoksal konsekvens af TOR's avancerede kalkulationer er at den ultimativt retfærdige arbejdsdeling mellem postbudene snarere viser sig at producere forskelle og potentiel uretfærdighed. Den meget håndfaste opmåling af tidsforbrug på ruten, således at alle ruter i princippet udgør den samme arbejdsbelastning, ender med at tydeliggøre de mange individuelle forskelle mellem postbudene. Forudsætningen for at udlægge alle ruter ens er at også alle postbude er det - en standardiseret rute fordrer et standardiseret postbud. Som planlæggeren påpeger:

(...) det var det som også var en af de grund- 
loeggende idéer med systemet. Det var at den ikke skulle lave individuelle fordi turene skal voere ens. Men problemet er jo lidt at sådan fungerer hverdagen ikke ude på et distributionscenter, fordi folk er ikke ens" (Regional planlægger)

Humlen er at postbude netop ikke er ens. Det er naturligvis ikke nyt i sig selv, men det rejser sig pludseligt som en uomgængelig problemstilling som følge af TOR. Det er noget den lokale ledelse må forholde sig til. Som en teamleder forklarer, så bliver hun nødt til at differentiere mellem sine medarbejdere; mellem de helt unge på 20 og de der har kørt post i 30 år og som følge heraf har slidte knæ. En fair rute vil i de to tilfælde netop ikke være det samme. Èn måde at takle det på er ved at benytte sig af visse 'låse' i systemet. F.eks. kan man låse systemet så visse gader forbliver samlet, inden man beder TOR om at lave en ruteomlægning, eller hvis det handler om et dårligt knæ, så kan man vælge at udlægge kortere ruter. Men det er naturligvis ikke omkostningsfrit. Det tager tid og kræver løbende forhandlinger. Hvilke individuelle forskelle skal i givet fald have lov at tælle som en forskel der udløser en undtagelse i TOR's beregninger? Derudover støder man hurtigt på et andet problem. Selve arbejdsbelastningen, i form af brevmængden, varierer nemlig i højere grad end det umiddelbart fremgår af TOR. Mens TOR opererer med et gennemsnitligt budget for det enkelte centers daglige brevproduktion, så er det reelt noget der fluktuerer fra dag til dag. Brevmængden er nu en gang ikke noget som kan forudsiges af organisationen, og det betyder at den samme rute ikke nødvendigvis tager lige lang tid at køre mandag som den gør om fredagen. Igen bliver spørgsmålet om hvad der reelt er en fair arbejdsdag til et åbent spørgsmål.

TORs måde at standardisere arbejdet på skaber med andre ord ikke kun orden, men også nye former for uorden, eller sagt på en anden måde: den producerer i sig selv nye koordinerings- og styringsbehov. Den stabilisering af ruterne og arbejdstiden som TOR's standardiserede beregninger i princippet burde repræsentere, er langt fra stabile. Den sorte boks genåbnes. Som en konsekvens heraf har man fra ledelsens side efterhånden ændret sin opfattelse af TOR fra det udviklingschefen kalder et 'stand alone system' til i stedet at betragte TOR som et 'støtteværktøj' i ruteplanlægningen. En god ruteplanlægning er i langt højere grad noget som kræver en løbende dialog mellem den lokale planlægger, teamlederen og det pågældende team. Som den Systemansvarlige i Post Danmarks hovedkvarter uddyber:

"Systemansvarlig: (...) når så hun [den anden planloegger] ligesom har fundet et billede af, hvordan er det verden ser ud i dag; om de ruter TOR siger er de største, rent faktisk er de største i Nordby, og de ruter der er de mindste rent faktisk også er de mindste ruter, og de ting der tager lang tid også tager lang tid inde i systemet, sådan så det hele passer sammen, så vi har fået et billede af hvordan virkeligheden er.

Interviewer: ... og det gør hun i en dialog? Systemansvarlig: Det gør hun i en dialog, ja. Og der er nogle steder man er rigtigt god til at tage den dialog, og der er nogle steder hvor det går lidt for hurtigt. Altså, hvor man simpelthen, det er hu hej vilde dyr. Og alt efter om man giver sig god tid, des mindre eftersloeb vil der vaere senere."

Det handler så at sige om at matche TOR's virkelighed med postbudenes, og i den proces har man måttet genindsætte de lokale (humane) aktører: planlæggere, lokale ledere og ikke mindst postarbejderne som væsentlige medspillere. De skal lære TOR at lave reelt funktionsduelige, effektive og retfærdige ruter. Men omvendt skal de også 
blive bedre til at 'se' ruterne sådan som TOR foreskriver. En teamleder taler om at forene det bedste fra to verdener - TOR's og postbudenes. Hvordan den forening foregår i forbindelse med ruteomlægningen vil være fokus i det følgende.

\section{Arbejdet og tiden genforhandlet}

I distributionscentrene er det sådan at man mere eller mindre hele tiden er i gang med ruteomlægninger som en følge af den drastisk faldende postmængde. TOR er her tænkt som et helt centralt og i princippet fleksibelt værktøj. I praksis kan en ruteplanlægningsproces dog ofte foregå endog meget håndholdt. Skal man tro den systemansvarlige, kan det ligefrem være en forudsætning for holdbare løsninger. Fra distributionscenter til distributionscenter, og i realiteten fra team til team, varierer processen. Nogle gange er det den regionale planlægger i samarbejde med TOR der kommer med et første udkast til nye ruter, som herefter kommer til gennemsyn hos teamet. I andre tilfælde vil det være teamet selv der kommer med forslag, som TOR herefter sættes til at regne på. Ifølge planlæggeren skal fordelene ved sidstnævnte ikke mindst ses i lyset af at blot en enkelt beregning kan tage op til en time for TOR. Eftersom planlæggeren servicerer flere distributionscentre på én gang, må den perfekte kalkulation løbende opvejes mod egne ressourcer og deadlines - og ikke mindst et ønske om umiddelbar funktionalitet - således at brevproduktionen kan køre så ubesværet som muligt:

"(...) man kan loegge rigtig meget ind i systemet, men så koster det også rigtigt meget tid. Så det er sådan noget med hvor man skal bruge tiden. Om man skal bruge det på det forberedende arbejde eller om man skal sige:' Jamen vi gør det manuelt, altså'. Det er en afvejning man hele tiden må gøre, ik'”.
Selvom TOR umiddelbart skulle fungere som et fleksibelt og ikke mindst ressourcebesparende element i ruteplanlægningen, så viser det sig ofte i praksis at være mere kosteffektivt at lade postarbejderne tage teten. Det betyder imidlertid ikke at alt i praksis er tilbage ved det gamle, som tiden før TOR. Det er nemlig ikke kun TOR der gradvist skal lære af postarbejderne. Postbudenes praktiske og lokale viden skal samtidigt tilpasses den logik og det blik TOR repræsenterer. Som den Systemansvarlige påpeger, så vil postarbejderne, selv direkte adspurgt, ikke være i stand til at svare på hvad det er TOR skal være særligt opmærksom på:

"Der er så mange ting, som når folk de kører post, som de ikke rigtigt toenker over, men som bare skal voere på en eller anden måde. Så selv hvis du spørger dem, så vil de ikke kunne svare"

Mens nogle postbude primært benytter sig af kort når de skal orientere sig på ruten, foretrækker andre at få en mundtlig forklaring kombineret med en oplistning af vejnavne, så de selv kan danne sig et (indre) billede af ruten. Den viden postbudene har om ruten, ligger ofte som en kropsligt indlejret viden der kan være vanskelig at sætte på ord. Den udfordring TOR stiller postbudene overfor er med andre ord at skulle lære hvordan TOR ser verden og følgeligt udlægger sine ruter, så de kan sætte fokus på (italesætte) netop den del af deres lokale og specifikke viden som systemet har brug for.

\section{Ledelse af ting og sociale relationer}

Som det fremgår ovenfor er ruteplanlægningen, selv i en standardiseret version, langt fra lige til. Det kræver en masse arbejde: koordinering og forhandling. Ruteplanlægning repræsenterer på den måde ikke 
blot en rationalisering og effektivisering af arbejdet, men tilfører samtidigt organisationen en ressourcekrævende arbejdsopgave. Selv efter en vellykket og dialogisk ruteudlægningsproces er koordineringsarbejdet ikke færdigt. Efter at have tilbragt tid i distributionscentret om morgenen er det således iøjnefaldende hvordan spørgsmålet om at matche brevmængden med arbejdstiden fortsat dukker op som emne for debat, konflikt og dermed som noget der skal ledes på og som involverer teamets sociale relationer. Ligesådan viser det sig at umiddelbart banale artefakter som eksempelvis labels, reoler eller nøgler til opgange og biler kan få den avancerede planlægning til at kollapse. Den organisatoriske 'alignment', som TOR skulle tilbyde, er med andre ord noget som dagligt skal opretholdes og genetableres, dels af de lokale teamledere og teams, dels af diverse artefakter. De 'banale' artefakter først:

Når jeg beder den lokale teamleder redegøre for hvad en ruteomlægning kræver, kommer hun med en fortælling som involverer en lang række aktører, mennesker såvel som ting, som hun skal forsøge at koordinere og holde sammen på. Det er en krævende proces, 'step by step' som hun udtrykker det, og den rejser en masse spørgsmål: Hvornår skal planlæggeren kontaktes i forhold til at levere et første udkast til ruter? Hvilke teammedlemmer skal inddrages og hvornår i processen? Hvornår skal TOR's første udkast udsættes for den første evaluering? Hvornår skal der printes nye adresselabels til de grå reoler? Hvem sætter dem op? Hvornår skal budstuen ommøbleres så den modsvarer den ny rutestruktur? Hvem skal have hvilke nøgler til opgange? Hvornår skal de omdeles og af hvem? Det kræver en stram koordinering af aktiviteter og ting, for at en ruteomlægning rent faktisk kommer til at fungere i praksis. Hvis en enkelt ting mangler: nøgler, vejlabels, den rette reolstruktur, risikerer det at bringe hele organiseringen og målet om 'post til tiden' i fare. Når det handler om de sociale relationer og den måde de dukker op som relevante for ledelse i forlængelse af TOR, så er det bedste eksempel de daglige morgenmøder $\mathrm{i}$ budstuen hvor forhandlingen af arbejdstiden tilsyneladende foregår ufortrødent.

\section{Hvem vil hjælpe?}

Hver morgen samler teamlederen teamet til et kort statusmøde for at sikre sig at alle er i stand til at køre deres ruter inden for den normerede arbejdstid. Selvom TOR i princippet tager ansvaret for at brevmængde og tid altid passer sammen, så er det, som vi så ovenfor, ikke altid at den budgetterede brevmængde matcher de 7, 24 timer. Som det sidste led i produktionskæden er det nu teamet og teamlederen der må sørge for at dette regnestykke alligevel ender med at gå op. Hvis et postbud har for lidt post i forhold til sin arbejdstid, er det teamlederens ansvar i samarbejde med det selvbærende team at fylde den tid ud, f.eks. ved at lade vedkommende hjælpe en kollega der på dagen har for meget post. Den følgende ordveksling stammer fra en optagelse af et morgenmøde i budstuen. Teamlederen står midt på gulvet, mens postbudene for en kort stund har vendt blikket væk fra deres grå reoler hvor de sorterer den ikkemaskinsorterede post op på deres respektive ruter. Udgangspunktet for dialogen er at personen der normalt kører rute 30, er syg, men det kunne i princippet have foregået en hvilken som helst morgen:

\footnotetext{
"Teamleder: Nå, nu har I fået noget post op og nogen er ved at pakke. Nu starter jeg med dem der har fået ekstra knallert. Det er 37 og 38 - hvad gør det for jer i forhold til at I ikke ellers får taget af [reduceret i postmængden]? P1: Jeg ved det ikke, jeg har aldrig kørt en knallert.
} 
Teamleder: Altså lige nøjagtigt dig derude og på knallert, dér er jeg ret fortrøstningsfuld P1: Ja, ja jeg skal nok nå det, det er no problemo

P2: Jeg når det også

Teamleder: Det er godt! Så har vi fire ture tilbage, der står med det stykke som ellers ville vore blevet kørt af 30'eren, og det er 31, 32, 34 og 40. Er der nogen der vil byde ind på at hjoelpe dem der så står på de ture?

P3: Jeg tager Højengen fra nummer 40

Teamleder: Jah...er der ikke andre der har noget at byde ind med?

P4: Jeg er godt proppet $i$ Blåboerhaven $i$ dag også...

Teamleder: Ja, men det kører du selv?

P4: Ja, det kører jeg selv, det er mere i forhold til at skulle hioelpe nogle andre...

P1: Martin aflaster sig selv!

[der grines]

Teamleder: Jamen, det er perfekt ... er der virkelig ikke andre der kan hjoelpe deres kollegaer?

P2: Hvad var det du sagde der var?

Teamleder: 31, 32, 34 mangler at få noget hjoelp nu - og jeg ved ikke om Hans har brug for mere?

[Der diskuteres frem og tilbage hvem der har mest behov for hjælp.]

Teamleder: Men Jesper står altså også med et kaempe problem her på 34'eren. Ikke nok med at turen var for stor i forvejen, nu ligger Nordby Bytorv også og roder på den..

Jesper: For en time ekstra, så kører jeg det hele.

[Ingen siger noget]

Teamleder: Okay. jeg vil sige, at det er lidt skuffende, at der ikke er flere [der vil hjælpe]."

Dialogen i teamet mellem teamleder og postbude skulle gerne illustrere det faktum at selvom hver enkelt rute er blevet udmålt, beregnet af TOR og efterfølgende forhandlet i en konkret ruteudlægningsproces, så kan daglige og selv meget små irregulariteter stadig destabilisere relationen mellem arbejdskraft og arbejdstid. Opgaven for teamlederen i samarbejde med det selvbærende team er nu at fordele arbejdsbyrden internt i teamet. Teamet forventes med andre ord at tage ansvar for irregulariteten og lede sig selv i forhold til produktionens krav. I Post Danmark satser man nemlig også på selvbærende teams. Som det fremgår, er det langt fra en nem opgave, hverken for den enkelte postarbejder eller for teamlederen. Teamlederen appellerer til teamets ansvarlighed og kollegiale hjælpsomhed, men mødes enten af jokes eller af en mur af tavshed. Den interne 'hjælpe-økonomi', som ellers fungerer i teamet, tillader teammedlemmerne ikke den lokale leder at komme i nærheden af. Men det er en anden historie, der desværre ikke er plads til her (se evt. kapitel otte i Mogensen 2012). Tydeligt bliver det uanset, dér på gulvet i budstuen, at TOR's kraft som standardiseringsværktøj i høj grad afhænger af de humane aktører som omgiver TOR. Uden en aktiv medvirken fra både lokale ledere og medarbejdere kan TOR ikke standardisere.

\section{Afsluttende diskussion}

Formålet med TOR, Post Danmarks avancerede ruteplanlægningssystem, er at samordne, koordinere og standardisere brevproduktionen. Der skal skabes organisatorisk 'alignment'. I praksis er det imidlertid åbenlyst at en sådan 'alignment' er ganske vanskelig at tilvejebringe. Analysen tydeliggør netop hvordan TOR's styringsambitioner co-producerer en masse nye problemer og 'ustyrligheder'. Den flade geografi, de individuelle forskelle mellem unge og gamle postbude, manglende nøgler eller tavsheden på morgenmødet; alle disse elementer viser sig hver især og tilsammen at kunne destabilisere TOR. Det der umiddelbart fremstår og 
er tænkt som en minutiøs standardisering og styring af omdelingen, det som man oplagt vil opfatte og kritisere som en ekstrem magtfuld detailstyring, repræsenterer således også en magtesløshed. En magtesløshed som samtidigt kalder på mere styring, flere aktiviteter og ikke mindst nogle medarbejdere som ikke blot er passive, men aktive medskabere af standarderne. Uden alt det, uden dette netværk af aktører og aktivitet, fungerer standardiseringen ganske simpelt ikke. Løbende dialog, udvidede samarbejder på tværs i organisationen, gensidig læring og selvbærende teams er alt sammen forudsætninger for at TOR kan opretholde sin agens, og altså standardisere.

Det er på den baggrund at artiklen argumenterer for at Post Danmark kan ses som et eksempel på hvordan bureaukratiske og post-bureaukratiske styreformer går hånd $\mathrm{i}$ hånd. Det betyder ikke at standardiseringen bliver mere 'blød', mere medgørlig, mere human fordi den kombineres med selv-ledelsesteknikker. Hybride styreformer handler ikke nødvendigvis, og slet ikke i dette tilfælde, om øget medarbejderautonomi. I postarbejdernes tilfælde handler selvledelse slet og ret om at fleksibilisere et ellers usmidigt system. Som en elefant på lerfødder. Tavsheden og den manglende hjælpsomhed i budstuen kan i forlængelse heraf ses som modstand, en sidste bastion. I modsætning til standardisering kræver selvledelse som ledelsesform nemlig en aktiv medarbejder, der taler, reflekterer og åbner sig/sit selv og på den måde gør sig tilgængelig for styring.

Det som er pointen med at pege på sameksistensen af styreformer, er først og fremmest at vi får øje på at standardisering ikke nødvendigvis opererer og virker som en følge af en optimal rationalisering, baseret på en skarp opdeling i planlægning og udførelse. Standardisering er ikke nødvendigvis lig med Taylor. I TOR's tilfælde er der åbenlyst meget og mange andre der produ- cerer styringen og standardiseringen end den ledelsesrationalitet som ligger i systemet selv. TOR's agens som ledelsesteknologi og standardiseringsværktøj er og bliver distribueret, og dermed bliver det også langt mindre entydigt hvad det egentlig er der får standardiseringen til at virke, eller til at bryde sammen. Konsekvensen er at det analytiske fokus må forskydes fra ledelsesrationaliteten og ledelsesteknologiens 'program' til de specifikke 'geographies of delegation', alias de specifikke forhandlinger mellem humane og non-humane aktører. Det er i disse forhandlinger at standardiseringens intenderede effekter enten stabiliseres, eller alternativt destabiliseres. Frem for at spørge til standardiseringens konsekvenser, hvilket forudsætter at vi allerede ved hvad standardisering er og gør, må vi i stedet spørge til hvordan standardisering får effekt. Som Latour minder os om med analogien om pistoler og pistolmænd, så ligger også standarders 'farlighed' i deres relationer og ikke i dem selv.

Det gør ikke en normativ diskussion af standardisering i arbejdet mindre væsentlig. Det giver den blot et andet analytisk afsæt. Et afsæt som ikke tager sit udgangspunkt i en prædefineret og generaliseret kritik af 'standardisering' som sådan; som formår at bevæge sig ud over en a priori modsætning mellem ledelse og medarbejdere; som formår at tænke relationelt og inddrage også non-humane aktørers betydning. Ved at insistere på beskrivelse forsøger artiklen at demonstrere hvordan også normative diskussioner må have et pragmatisk og empirisk specifikt udgangspunkt. I Post Danmark er der ingen tvivl om at standardiseringen - hvilket de facto indebærer en hybridisering af styreformer - gør medarbejderne mere sårbare. Mens de med den ene hånd bliver bedt om at arbejde i gnidningsløs forlængelse af produktionsapparatet, bliver de med den anden opfordret til at forholde 
sig reflekteret, ansvarligt og fleksibelt i forhold til den uforudsigelighed som markedet, men altså også standardiseringen selv producerer. Det er en problemstilling som ledelsen i Post Danmark er opmærksom på, men som af mange grunde har svært ved at finde en løsning. I en situation hvor postmængden skrumper ind dag for dag, hvor international konkurrence er et vilkår, men samtidigt flankeres af statens krav om befordringspligt, bliver spørgsmålet om fremtidens organiseringsform og postarbejderens rolle i forlængelse heraf ikke lettere at definere. Bliver det 'robotten' eller den selvledede 'servicemedarbejder' der fremover skal trække i den røde uniform? Standardiseringsprocesserne i Post Danmark peger i øjeblikket i begge retninger.

\section{NOTER}

1 Paul Du Gay tager udgangspunkt i det weberianske offentlige bureaukrati og bureaukritikken, men ser man på den engelske og amerikanske forskningslitteratur, så er der en tendens til at kritikken af det weberske bureaukrati og Taylors 'scientific management' ofte løber sammen og repræsenteres ved termen 'bureaucracy' og med samme modbillede og alternativ: 'post-bureaucracy' (Alvesson \& Thompson 2005; Adler 1993; Adler \& Borys 1996).

2 Det er væsentligt at bemærke at Taylors 'scientific management' ikke blot kan læses som en måde at kontrollere arbejderne på, men i lige så høj grad handler om at afrette lederne. Deres usystematiske og personlige tilgang til ledelse opfattede Taylor som et lige så stort problem for virksomhedens produktivitet som medarbejdernes dovenskab (Taylor 1903; Kjær 2014).
3 I Alvesson og Kärremans artikel med titlen "Cages in tandem: Management Control, Social Identity, and Identification in a Knowledge-Intensive Firm" refererer de således til Webers idealtypiske læsning af bureaukratiet som et jernbur. Dermed defineres ikke blot bureaukratiet, men altså også post-bureaukratiet ved sin særlige - og tvingende rationalitet (Alvesson \& Kärreman 2004).

4 Udover Post Danmark indgik to folkeskoler og biotek-virksomheden Novozymes som cases (se f.eks. Olesen 2011; Andersen \& Bramming 2011)

5 Navnet på det specifikke distributionscenter og område er anonymiseret her. Interviewene tæller: den systemansvarlige, som har haft ansvaret for udviklingen af ruteplanlægningssystemet, den regionale HR-chef, ruteplanlægger og driftudviklingschef samt en lokal teamleder.

Cambridge, MA, The MIT Press.

Allvin, M. et al. (2011): Work without Boundaries. Psychological Perspectives on the New Working Life, Chichester, John Wiley \& Sons Ltd. Alvesson, M. \& P. Thompson (2005): PostBureaucracy?, i S. Ackroyd, R. Batt \& P. Thompson (red.): Oxford Handbooks of Work and Organization, Oxford, Oxford University Press. 
Alvesson, M. \& H. Willmott (2002): Identity Regulation As Organizational Control: Producing the Appropriate Individual, i Journal of Management Studies 39, 5, 619-644.

Alvesson, M. \& D. Kärreman (2004): Interfaces of control. Technocratic and Socioideological Control in a global management consultancy firm, i Accounting, Organization \& Society, 29, 423-444.

Andersen, V. \& P. Bramming (2011): Selvledelse - det moderne arbejdslivs organiseringsform. Erfaringer fra TRIPS projektet, i Det Danske Ledelsesakademis Konference.

Braverman, H. (1974): Labor and Monopoly Capital. The Degradation of Work in the Twentieth Century, New York, Monthly Review Press.

Bovbjerg, Kirsten Marie (2003): Selvets disciplinering - en ny pagt i arbejdslivet, i Tidsskrift for Arbejdsliv, 3, 42-57.

Buch, A., V. Andersen \& O.H. Sørensen (2009): Videnarbejde og Stress - mellem begejstring og belastning, København, Jurist- og Økonomforbundets Forlag.

Callon, M. \& B. Latour (1981): Unscrewing the big Leviathan: how macro actors structure reality and how Sociologists help them to do so, i M. Callon \& B. Latour (1981): Advances in social theory and methodology: toward an integration of micro-and macrosociologies, New York, Routledge.

Callon, M. (1986): Some elements of a Sociology of Translation: domestication of the Scallops and the Fishermen of St. Brieuc bay, i J. Law (red.): Power, Action and Belief: A new Sociology of Knowledge, London, Routledge \& Kegan Paul.

Du Gay, P. (2000): In Praise of Bureaucracy. Weber, Organization, Ethics, London, Sage Publications Ltd.

Grey, C. (2009): A very short, fairly interesting and reasonably cheap book about studying organizations, London, Sage Publications Ltd.

Gudiksen, J. (2007): Moderne Ledelse som Double-bind Kommunikation, i Tidsskrift for Arbejdsliv 9, 2, 67-80.

Hvid, H. et al. (2010): Associational Control: Between self-management and standardization in the financial sector, i Economic and Industrial Democracy, 31, 639-659.
Karasek, R. A. (1979): Job Demands, Job Decision Latitude, and Mental Strain: Implications for Job Redesign, i Administrative Science Quarterly, 24, 2, 285-308.

Kärreman, D. \& M. Alvesson (2004): Cages in Tandem: Management Control, Social Identity, and Identification in a Knowledge-Intensive Firm, i Organization, 11, 1, 149-175.

Kärreman, D. et al. (2006): The Charismatization of Routines: Management of meaning and standardization in an educational organization, i Scandinavian Journal of Management, 22, 330-351.

Kärreman, D. et al. (2002): The Return of the Machine Bureaucracy. Management Control in the Work Settings of Professionals, i International Studies of Management. \& Organization, 32, 2, 70-92.

Kjær, Peter (2014): Scientific Management, i P. Kjær \& S. Vikkelsø (red.): Klassisk og moderne organisationsteori, København, Hans Reitzels Forlag (in print).

Kunda, Gideon (1992): Engineering Culture, Control and Commitment in a High-Tech Corporation, Philadelphia, Temple University Press.

Latour, B. (2005): Reassembling the Social. An Introduction to Actor-Network-Theory, Oxford, Oxford University Press.

Latour, B. (1999): Pandora's Hope: Essays on the reality of science studies. Cambridge, MA, Harvard University Press.

Latour, B. \& S. Woolgar (1986): Laboratory Life. The Construction of Scientific Facts, Princeton, NJ, Princeton University Press.

March, J. \& H. Simon (1958): Organizations, New York, John Wiley \& Sons.

Mogensen, B. (2000): Humanising the Engineer - or the story of how the teacher and the engineer got married, i Ledelsesidéernes historie, Kompendium, Cand.merc., 3. semester. Samfundslitteratur, København, 2000 (upubliceret).

Mogensen, M. (2012): The Organization(s) of Well-being and Productivity - (Re)assembling work in the Danish Post, PhD series, nr. 38, Frederiksberg, Copenhagen Business School. Morgan G. (1989): Creative Organization Theory, Newbury Park, Sage Publications.

Olesen, K.G. (2011): Organizing Schools, mana- 
ging Teachers - a Qualitative Inquiry into the Practices of Teaching, School Management and Collaboration in Danish Schools. PhD Thesis, CBS. Submitted Nov. 2011. Under revision.

Roethlisberger, F.J. \& W.J. Dickson (1964): Management and the worker: an account of a research program conducted by the Western Electric Company, Hawthorne Works, Chicago, by FJ Roethlisberger and William J. Dickson, with the assistance and collaboration of Harold A. Wright, Cambridge, MA, Harvard University Press.

Rose, N. (1990): Governing the soul: The shaping of the private self, London, Taylor \& Frances/ Routledge.

Taylor, F.W. (2004): The Principles of Scientific Management, E-book: Maneybooks.com. (http://www.enebooks.com/data/JK82mxJBHsrAsdHqQvsK/2010-01-19/1263902254.pdf).

Taylor, F. W. (1903): Shop management, New York, American Society of Mechanical Engineers. Tynell, J. (2002): "Det er min egen skyld" - nyliberale styringsrationaler inden for $\mathrm{Hu}-$ man Resource Management, i Tidsskrift for Arbejdsliv 4, 2, 7-24.

Mette Mogensen, arbejdsmiljø- og arbejdslivsforsker, TeamArbejdsliv

e-mail:memo@teamarbejdsliv.dk/mmo.ioa@cbs.dk 